\title{
Selective Reading and Misconstrued Biblical Text: A Case for the Inclusion of Women in Church Governance Structures in Black South African Churches
}

\author{
Dr Zandisile M. Dweba* - PhD Candidate - zandidweba@telkomsa.net \\ University of Fort Hare - Alice, South Africa \\ Rev Nkosinati M. Mbali - PhD Candidate \\ University of Fort Hare - Alice, South Africa \\ Prof Reuben Z. Rashe \\ University of Fort Hare - Alice, South Africa \\ Doi: https://doi.org/10.46222/pharosjot.10214
}

\begin{abstract}
This article is a sequel to our article on the marginalisation and exclusion of women from the church governance structures in the Black South African churches. While numerous stereotypes were discussed in our previous article, that justified the exclusion of women, the authors in this article argue for a theological and Biblical basis for their inclusion in both the ministry and governance positions in Black South African churches. The authors followed a literature review approach in this article. In the literature reviewed, texts were unearthed which support the inclusion of women and the need for the consciousness with which Scripture must be read, understood and applied, to help the reader identify the value added by the discussion of the role of women in church leadership positions and ministry with an open mind. The approach which the authors adopted was to, having cited the texts that support the argument for the inclusion of women, treat the texts justly, perusing the Bible widely instead of selecting verses that seemingly support a favoured argument. Among the compelling findings, which revolved around equality, was that God created both man and woman to share dominion over the earth. All through their baptism, constitute the body of Christ; the Great Commission which Jesus commanded his disciples was an instruction to men and women equally; men and women in the Bible have served God in different capacities; When the Holy Spirit bestowed the spiritual gifts, this was meant for all those who constitute the body of Christ; and while the Old Testament emphasises priesthood for males only, the New Testament presents the priesthood of all believers.
\end{abstract}

Keywords: Inclusion, governance, ministry, gender, women, equality.

\section{Introduction}

Crucial to the deliberation about what role women should play in church leadership and ministry is faithful Biblical interpretation, as argued by Scholer (1984). While this may seem like a dated assertion, numerous scholars concur with Scholer that the assertion still holds today (Fiorenza, 1988; Tolmie, 2014; Marshall, 2017; Peterfeso, 2020). Tolmie (2014) argues further that in recent studies done on Paul's Epistle to the Galatians 3:28, for instance, varying tendencies on how this scripture is interpreted and presented have been observed. It is not the intention of the authors to zero in on this particular scripture, but rather to traverse both Testaments of the Bible, identifying possible scriptural misinterpretations, identifying those scriptures that provide a basis for the inclusion of women in ministry and highlighting the implication of these for the church and society. What makes the role of women ministry difficult to explain is the influence of their societal position on their role in the church. Amid the contextual challenges, it is the intention of the authors to find and argue for the theological and 
Biblical basis for, among others, the ecclesiastical role which women must play in the church (D'Cunha, 1995).

While some scholars such as Piper (1991: 22) in Macallan and Hendriks (2013: 146) hold the view that, "The Bible teaches that men and women fulfil different roles in relation to each other, charging men with a unique leadership role, it bases this differentiation not on temporary cultural norms but on permanent facts of creation", Pierce and Groothuis (2005: 13) in (Piper, 1991: 146) hold a different understanding though, that:

Gender, in and of itself, neither privileges nor curtails one's ability to be used to advance God's kingdom or to glorify God in any dimension of ministry, mission, society and family. The differences between men and women do not justify granting men unique and perpetual prerogatives of leadership and authority not shared by women.

Given these divergent views, Hanson (1986) advises that the Bible as the sole and central reference of the Christian community must always be used to guide reflection on theological matters.

\title{
Old Testament Scriptures
}

While the subject of women in ministry and leadership tends to be seen as primarily a New Testament discussion, numerous Old Testament scriptures must be considered to do justice to the subject. Among the Old Testament scriptures, Genesis 1:26-28 (NRSV) seems to set the tone when God pronounced:

\begin{abstract}
26 ... Let us make humankind in our image, according to Our likeness; and let them have dominion over the fish of the sea, and over the birds of the air, and over the cattle, and over all the wild animals of the earth, and over every creeping thing that creeps upon the earth.

${ }^{27}$ So God created humankind in His image; in the image of God, he created them; male and female he created them.

${ }^{28}$ God blessed them, and God said to them, "Be fruitful and multiply, and fill the earth and subdue it; and have dominion over the fish of the sea and over the birds of the air and over every living thing that moves upon the earth.
\end{abstract}

The foregoing scripture carries God's proclamation that He deliberately created both male and female in His likeness and that He bestowed dominion equally to both. In Exodus 38:8 when Moses was instructed by God to build the tabernacle to house the Ark of the covenant, he was specifically ordered to make the laver from the bronze mirrors supplied by the Israelite women who served at the Tabernacle door and who were then anointed with holy oil along with the Tabernacle and the priests. While these women are identified specifically as having played a role in worship, of importance, is that they are mentioned for the leadership roles they played. Their naming provides a basis in the Old Testament for the inclusion of women in both ministry and church leadership. In the 2 Kings 22:14-20 and Exodus 15: 20-21 scriptures, reference is made to Miriam and Hudah as prophetesses who played a significant role in fulfilling God's purpose, respectively. Similarly, in Judges 4-5, Deborah is cited as a prophetess, judge of Israel and a leader in a time that was challenged by conflict. Littler (2007) supports the argument for the inclusion of women in ministry when he writes that women are more inclined to be inclusive in their approach compared to men. This, he argues alongside RaymentPickard and Shakespeare (2006) that, the church must be inclusive of all genders and races. This inclusion, he argues, must not be merely the church's desire to be politically correct, but must be Biblically based and in keeping with Jesus' identity and values. The values are a Gospel imperative and are "...fundamental to the very nature of God and at the very heart of the mission of Jesus Christ" (Fraser, 2006: 320). 


\section{New Testament Scriptures}

The freedom brought about by Christ presents a markedly different view from the negativelyinclined which characterises the ancient societies. Because the women of the time were largely uneducated, the rabbis who were the religious leaders of the time, warned against teaching scripture or law to the women. As such, women, regardless of whether or not they were rich or poor, educated or uneducated, spent most of their time in the confines of the home. Women were not even considered necessary people to reach the quorum for the constitution of a synagogue. In the Acts, women are frequently mentioned as having participated as the founding members of the Church. In Acts 1:14 the devotion of women to prayer is highlighted while in Acts 8:3 Saul, in persecuting those who followed Jesus' teachings, indiscriminately "...dragged away men and women and put them in prison". The women's involvement went beyond praying but are counted among the many who received the Gospel (Acts 17:12), "Therefore many of them believed, and also not a few of the Greeks, prominent women as well as men".

In the book of Acts 21, it is unequivocally stated that the church of Philippi was founded on women, with Paul confirming that, when they paused at Caesarea at the house of the evangelist Phillip on their voyage to Jerusalem, they found him with his four unmarried daughters who were prophetesses (Acts 21:9). Paul clarifies the foregoing assertion once more in the Galatians 3:28 when he passionately dispels any idea of imposing barriers to the recognition of women as leaders and their inclusion in ministry, be these barriers racial, societal or sexual, when he writes that, "There is neither Jew nor Greek, there is neither slave nor free, there is no male and female, for you all are one in Christ Jesus".

The oneness that Paul refers to in the foregoing scripture must be understood not to be merely referring to one's standing with God or simply the oneness to be found at Christ's second coming. It is about the present, for it forms the foundation on which Paul rebukes Peter for his hypocrisy for refusing to share a meal with the Greeks in Antioch. While the details of the various women that Paul mentions in his epistles, the language that he uses of himself and his male aides is the same that he uses of the females. In his letter to the Romans, he mentions ten of these women who were engaged in different ministries.

Among the women that Paul names are Phoebe who is believed to have delivered Paul's letter to the Romans. The Greeks described her as the diakonos, which translated means deacon or one who helped many (Romans 16:1,2). Paul, in Romans 16:3, refers to Aquila and Priscilla as his colleagues. How he introduced them to the Romans, bears testimony, "Greet Priscilla and Aquila, my co-workers in Christ Jesus". Paul further accolades Priscilla for having opened a church in her and her husband's house, which is credited for converting Apollos, the firstcentury Alexandrian Jewish Christian (Acts 18:26).

Paul further names four more women, Mary, Tryphaena, Tryphosa and Persis whom he recognised for having laboured in the Lord (Romans 16:6,12). The apostle Junia, a woman, is also named in Romans 16:7. Finally, two more women, Syntyche and Euodia are said to have worked with Paul in spreading the Gospel. Embedded in 1 Corinthians 11:5 is an overlooked message that women prayed and prophesied in the early Church, "But every woman who prays or prophesies...". The tendency in translating this scripture by many is to erroneously focus on its latter part, instead of its primary message that women prayed and prophesied.

Often, when people oppose the ordination of women as ministers and their inclusion in leadership, this is not Biblically based but based many times on the authority itself. They normally do not have a plausible explanation as to why men must have authority and women, not. They often mistakenly apply the text that deals with the husband-wife relationship to the question of women in ministry. Most incorrect is when people assume this worldview on authority which Christ himself refutes sharply in Matthew 20: 25-28 when He commanded His disciples not to follow the world's view of authority as it is flawed and ought to be rejected. 
Langley (1989) argues that the correct interpretation that Christians should follow, is that which focuses on the oneness shared by all Christians. This oneness must be characterised by the equality of all the people of God. This, she argues, must not be contaminated by social, cultural or political factors. This is contention is strengthened in Paul's letter to the Galatians 3: 26-28, that:

\begin{abstract}
${ }^{26}$ For you are all children of God, through faith, in Christ Jesus. ${ }^{27}$ For as many of you as were baptized into Christ have put on Christ. ${ }^{28}$ There is neither Jew nor Greek; there is neither slave nor free; there is no male and female. For you are all one in Christ Jesus.
\end{abstract}

Notwithstanding the foregoing teaching by Jesus, many who are opposed to Christ's view still argue, using Paul and his successors who they contend, spent a lot of time moderating the enthusiasm of many churches, inspiring them to follow patriarchal norms and hierarchical culture. This, they conveniently based on the scriptures in 1 Corinthians 11 and 14; 2 Corinthians 11; Colossians 5; 1 Timothy 2; Titus and 1 Peter 2-3, which encourage the submission of wives to their husbands (Langley, 1989:27). While Paul in the Galatians 3 asserts the inclusion of women in ministry, Langley (1989:28) laments that the New Testament provides no guidelines for such a ministry. As a result of the absence of a template, "...Scripture, tradition and reason come into play as the church seeks a ministry appropriate to the demands of mission in the contemporary world" (Thorsen, 2020:164). At the time of reformation, such Protestants as Martin Luther wanted to return the ministry to the laity, arguing that all people should be allowed to participate in the ministry. This, in 1 Peter 1:9 is referred to as the ministry of all believers and that these people are "a chosen race, a royal priesthood, a holy nation, God's people, so that you may proclaim the mighty acts of Him who called you out of darkness into His marvellous light" (Thorsen, 2020:164). Luther argued that all Christians were called to minister, and he exhorted all congregants to contribute in ministry to people, both within and outside their churches. Their callings, he argued, were to many vocations thought necessary to grow the congregation and not necessarily to church leadership.

Kasomo (2010) who writes from an African Theology point of view reviews the role played by women in African Instituted Churches (AICs) when he argues for a change of men's attitude towards women who still see women as lesser people, unable to lead or serve as ministers. He cites the scriptures, "All baptized in Christ, you have all clothed yourselves in Christ and there are no more distinctions between Jew and Greek, slave and free, male and female, but all of you are in Christ Jesus" (Gal. 3:28); and "And you are all brothers and sisters" (Matt. 23:8). The essence of this scripture is that in the Gospel all distinctions are done away with all are equal and welcome to Christ regardless of their race, social status or gender. The brotherhood and sisterhood referred to are not merely based on being the descendants of Adam but as being in a spiritual relationship with God with no one enjoying a superior status over the other, that is, enjoying equal rights and privileges before God.

Wright (2006) is however critical of the foregoing version of the Galatians 3:28 that the Scripture is not the first or only time Paul talks about men and women in the Bible. He argues that instead of arranging Pauls scriptural texts about men and women in a hierarchy, analysts need to do justice to what Paul means in the Scripture. He argues that Paul's point is that God has one family, constituted of all those who believe in Christ - the family that He promised to Abraham. Nothing, he contends, must hinder this promised oneness that is discovered in the faithfulness of the Messiah. His exegetical analysis of the Scripture is that "...there is neither Jew nor Greek, neither slave nor free, no male and female". In his Scripture, Paul, Wright (2006) quotes Genesis 1:27, which reads, "So God created man in His own image; in the image of God He created him; male and female He created them". He argues that Paul as a new creation theologian is continually concerned with renewal and consistently reaffirms God's creation. This affirmation he reiterates in Galatians 6:16, Romans 8 and 1 Corinthians 
15, to mention but a few. In this light, Genesis 1:27 must inform and guide the understanding of Paul's writings (Wright, 2006).

Notwithstanding that Jesus had chosen male disciples, there is no doubt that there were numerous reasons, cultural, symbolic or otherwise for His choice. The practical and cultural world in which the disciples had to operate, would likely not be conducive for women. Given the foregoing, it cannot be denied that it is the women who came first to the tomb after all Jesus' male disciples had abandoned Him; and were the first to be entrusted with the news of His resurrection. Wright (2006) argues that, if witnessing the resurrection of Jesus was how an apostle was defined the three women who were first at Jesus' grave deserved the title before any of the men, "And when the sabbath was past, Mary Magdalene, and Mary the mother of James, and Salome, had bought sweet spices, that they might come and anoint him" (Mark 16:1).

The authors propose what the church can do to change the current mindset, empower women and create a conducive environment for the inclusion of women in mission and outreach. This practice must, of course, be based on proper and gender-sensitive Biblical interpretation. Mbayo and Nyakora (2018) argue that church mission and outreach must be approached holistically in the church and not just done to reach numerical targets, but that the involvement of women in attaining mission and outreach need to be highlighted and challenges mitigated. Mechanisms must be developed, they argue, on how to include women in all church activities, including ministry and leadership. At the heart of women inclusion, must be a conscious creation of a safe environment where women feel safe and their contributions valued. Such attitude would be the replication of Jesus' deeds as when He had an intense conversation with the Samaritan woman, an outcast who subsequently evangelised the whole Samaritan city of Sychar (John 4). When a woman was caught in adultery, Jesus protected her and encouraged her to change her ways (John 8). He also defended the mothers who brought their children to Him (Mark 10). On the cross, while facing imminent and certain death, Jesus arranged for John, the disciple that he loved so much, to look after His mother, Mary (John 19). He stopped those who criticised a sinful woman who rubbed His feet with expensive perfume and declared, "Wherever this Good News is preached in the entire world, this woman will be remembered for what she has done" (Matthew 26:13, KJV).

The subject about the inclusion of women in ministry, Mbayo and Nyakora (2018) contend, must be Biblically-based and directly connected to correctly interpreted Scripture. Churches must develop policies that enable inclusivity in the church and its mission. Finally, while practice is a matter of pragmatism, policy implementation must not compromise the theological principles on which the practice is founded. What is more, Wright (2006) proposes, churches must carefully consider what effect their prejudices, culture and anger have on how women are treated. They must make sure that stereotypes are eliminated and that liberating, healing and humanising messages and practice based on the Gospel of Christ manifest.

Among the possible solutions, is to challenge the stereotype that men are better than women in leading congregations. There is a need for inclusive practices if the future well-being of the church is to be safeguarded. Oduyoye and Amoah (1996) agree with Ackermann (1991) when they assert that the concept of the Imago Dei, is represented by the partnership of women and men, whether or not they are ordained - that, women's desire to be ordained, should not be seen as their wish to supplant men. The need for gender sensitisation and training across all the levels of the church hierarchy patriarchy and its downside. Such training should be done on a case study, role-play and interactive basis and be aimed at, among others, for women to break their silence. To sustain and anchor the achievements, a gender desk would need to be established to facilitate permanency (Sparrow, 2007).

Untangling the gendered aspect of leadership success or whether or not women are better leaders, is something of a puzzle and has in many situations, divided scholars and laypeople, 
alike - with Hastings and Lindsay (2013) vouching for the superior spirituality and prayerfulness of women. Further exacerbating the problem, is the fact that not enough has been written about the effect of gender on leadership success. Some scholars, like Sinclair (2005) and Carver (2006), outline three levels at which effective leaders operate, that is, appearance, process and policy. They assert that gender impacts all three levels, suggesting that, gender is integral to the leader's image. He asserts that indigenous women leaders use their appearance to distinguish themselves, to create a comfortable leader-follower environment and thus increase trust.

Parity between men and women was reiterated by Sibotho (2020), when he cited Article 3 of the Ethiopian Episcopal Church's 'Declaration of Faith' (EECSA, 1999), that, the church acknowledged that all humanity was created in the image of God, and that, the church, recognised the historical and social tendencies to denigrated women, ... and rejects these, as in conflict with to the vision of the dignity and worth with which the human person was endowed by God at creation, and which was wonderfully restored in Jesus Christ. He cites the distinctive contribution of women, for not only their contribution to the financial stability of the church but also for being the fibre of spirituality in the church. Sibotho (2020), raises the question, of whether or not, men are perhaps jealous of women. Alluding to women's spirituality, and in agreement with Hastings and Lindsay (2013), Sibotho (2020) cherished the prayerful nature and the role women played in engulfing church gatherings with their prayerful presence. Mtuze (2008) proclaims that it was Dwane's interest in the ordination of women that soured his relations with his conservative leaders in the Ethiopian Episcopal Church. The cause of the emancipation of women in the church, was not unique to the Ethiopian Episcopal Church, as is evident in Mbuy-Beya (1996:175) assertion in Mtuze (2008:146), that:

The position of women in African societies is not a pretty picture. The Circle of African Theologians has already condemned the deplorable situation of women. The group has been working tirelessly so that each woman and each man might be recognized as a child of God, sharing equally in human dignity. Women do not lead this fight alone; more and more men are supporting them. Moreover, what these women are fighting for is not uniformity between themselves and men; rather, they want to be fully women in society as well as in the Church.

The short-sighted argument of Dwane's distractors regarding the ordination of women into the priesthood was based on their understanding of the Scripture that, if God, in His revelation, had designated only men to be leaders, the inclusion of women in ministry, would contradict God's revelation. Dwane's counterargument was that the revelation was not a fixed deposit of truths in the doctrine or Bible, but a personal relationship between God and His people. He argued that this revelation could not be fixed to when the Scripture was written, but must flow with the work of the Holy Spirit, God continues to reveal Himself and that, the understanding of the relation between Him and His people, is forever deepening. About the equality of men and women, Dwane (1989:9), asserts that:
Man] and woman are co-creators with God. Therefore, we cannot attain the full liberty of God's children until we recognize that man and woman are equal and complementary. The struggle for women's rights is as important as the struggle for liberation from oppression. As members of God's family, we are an extension of God himself.

It has become obvious, at this point, that, any effort to exclude women from participating in leading the church and society, is likely to be resisted from within and outside the church, by those who believe and fight for equality. In his final declaration, Dwane proclaimed that nothing should stand in the way of women inclusion in leadership and ministry. Finally, as highlighted in the Catholic Inter-regional Meeting of the Bishops of South Africa (IMBISA) in Africa Faith and Justice Network: 


\begin{abstract}
Women are the backbone of the church in Africa. Women recognize that Christ in his Church, symbolized by Mary his mother, gives them their full human dignity and they accept this good news with joy, precisely because society at large in many ways fails to accord them proper respect. As a result, the Church must promote the full human dignity of women. As coworkers of Christ and essential agents of evangelization, they seek their proper place in the ministry and leadership of the church. Like the laity as a whole, women need to be given better formation and be offered greater responsibility within the Christian community (IMBISA, 1996:48).
\end{abstract}

\title{
Conclusion
}

In summary and as can be deduced from the stand taken by the first bishop of the Ethiopian Episcopal Church, Bishop Sigqibo Dwane, it can be concluded that he advocated for women's rights, their ordination to ministry and their acceptance to church leadership, to the bitter end. This, he did at the expense of enduring contempt and malevolence from his detractors. Notwithstanding the efforts by such advocates, women still lack opportunities for inclusion in church leadership and ministry. There are several hindrances such as cultural and religious stereotypes as noted in our last article (Dweba, Mbali \& Rashe, 2020). We must agree with the women who assert that Black Theology should not enjoy the status of liberation theology unless it has as one of its priorities, the emancipation of women. The authors support the oneness as embodied in Jesus Model of Liberation, where all through their baptism, constitute the body of Christ. It is the authors' observation, gleaned from the review literature that, a large number of problems that hinder the inclusion of women in ministry and leadership positions, especially in Black churches in South Africa, originate from the many societal gender stereotypes. It is cannot be denied from the scriptures discussed in this article, that the church needs the gifts and abilities of women as much as those of men.

\section{References}

Ackermann, D. (1991). Being Woman, Being Human. Pietermaritzburg: Cluster Publications.

Carver, T. (2006). Politics of Identity. Government and Opposition, 41(3), 450-468.

D'Cunha, J. (1995). Should Women Be Ordained? Debate in Roman Catholic Church. Economic and Political Weekly, 30 (2), 85-86.

Dwane, S. (1989). Issues in the South African Theological Debate. Braamfontein: Skotaville Publishers.

Dweba, Z. M., Mbali, N. M. \& Rashe, R. Z. (2020). Marginalisation and Exclusion of Women from the Church Governance Structures: Experience in Black South African Churches. Pharos Journal of Theology, 101, 1-14.

EECSA. (1999). Declaration of Faith. Grahamstown: Ethiopian Episcopal Church.

Fiorenza, E. S. (1988). The Ethics of Biblical Interpretation: Decentering Biblical Scholarship. Journal of Biblical Literature, 107 (1), 3-17.

Fraser, G. (2006). Forward, in H. Rayment-Pickard and S. Shakespeare, The Inclusive God: Reclaiming Theology for an Inclusive Church. Norwich: Canterbury Press.

Hanson, P. D. (1986). The People Called: The Growth of Community in the Bible. San Francisco: Harper \& Row. 
Hastings, O. P. \& Lindsay, D. M. (2013). Rethinking Religious Gender Differences: The Case of Elite Women. Sociology of Religion, 74 (4), 471-495.

IMBISA. (1996). Africa Faith and Justice Network: Africa Synod - Documents Reflections, Perspectives. New York: Orbis Books.

Kasomo, D. (2010). The Role of Women in the Church in Africa. Sociology and Anthropology, Vol. 2 (6), 126-139.

Langley, M. S. (1989). One Baptism, One Ministry: The Ordination of Women and Unity in Christ. Transformation, 6(2), 27-31.

Littler, K. (2007). The Ordination of Women and Inclusivity within the Church: Theological and Psychological Considerations. Archive for the Psychology of Religion, Vol. 29, 319-324.

Macallan, B. \& Hendriks, H. J. (2013). Post-Foundational Practical Theology as Correlational Hermeneutic. Acta Theologica, 33(1), 135-157.

Marshall, J. E. (2017). The Recovery of Paul's Female Colleagues in Nineteenth-Century Feminist Biblical Interpretation. Journal of Feminist Studies in Religion, 33(2), 21-36.

Mbayo, D. M. \& Nyakora, M. O. (2018). Women Leadership, The Scriptures and Empowerment: How Training in Leadership Can Shape the Destiny of Women in Church Ministry. International Journal of Scientific \& Engineering Research, 9(3), 229-247.

Mbuy-Beya, B. (1996). Women in the Church in Africa, in African Synod: Documents, Reflections, Perspectives, Africa Faith \& Justice Network. New York: Orbis Books.

Mtuze, P. T. (2008). Bishop Dr S, Dwane and the Rise of Xhosa Spirituality in the Ethiopian Episcopal Church (Formerly The Order of Ethiopia) - Unpublished Doctor of Theology Thesis. Pretoria: University of South Africa.

Oduyoye, M. A. \& Amoah, E. (1996). The Christ for African Women. New York: Orbis Books.

Peterfeso, J. (2020). Women priests Bodies in Persona Christi. New York: Fordham University Press.

Phiri, I. (2004). African Women's Theologies in the New Millenium. Agenda: Empowering Women for Gender Equity, 61, 16-24.

Pierce, R. W. \& Groothuis, R. M. (2005). Discovering Biblical Equality: Complementarity Without Hierarchy. Downers Grove: IVP.

Piper, J. (1991). A Vision of Biblical Complementarity: Manhood and Womanhood Defined According to the Bible. Wheaton: Crossway.

Rayment-Pickard, H. \& Shakespeare, S. (2006). The Inclusive God: Reclaiming Theology for an Inclusive Church. Norwich: Canterbury Press.

Scholer, D. M. (1984). A Biblical Basis for Equal Partnership: Women and Men in the Ministry of the Church. San Francisco: Fuller House.

Sibotho, L. (2020). Second August Memorial Lecture: The Struggle of the Church to Achieve Parity Between Men and Women: What Decisions were taken in this Regard and the Impact 
it had on the 1991 Break Away by the Disaffected People? (pp. 1-7). Makanda: Ethiopian Episcopal Church.

Sinclair, A. (2005). Body Possibilities in Leadership. Leadership, 1(4), 387-406.

Sparrow, I. (2007). Fighting Male Supremacy in a Church Context. Agenda: Empowering Women for Gender Equity, 71, 131-137.

Thorsen, D. (2020). Priesthood of All Believers. Claremont: Claremont Press.

Tolmie, D. F. (2014). Tendencies in the Interpretation of Galatians 3:28 Since 1990. Acta Theologica, 19, 105-129.

Wright, N. T. (2006). The Biblical Basis for Women's Service in the Church. Priscilla Papers, 20(4), 1-10. 
Pharos Journal of Theology ISSN 2414-3324 online Volume 102 - (2021)

cc. (i) $(-)$ Copyright: @2021 Open Access/Author/s - Online @ http//: www.pharosjot.com 
Pharos Journal of Theology ISSN 2414-3324 online Volume 102 - (2021)

(c) 1 (i) $(-)$ Copyright: @2021 Open Access/Author/s - Online @ http//: www.pharosjot.com 